Jurnal Basicedu Volume 4 Nomor 2 April 2020 Hal. 396-401

JURNAL BASICEDU

Research \& Learning in Elementary Education

https://jbasic.org/index.php/basicedu

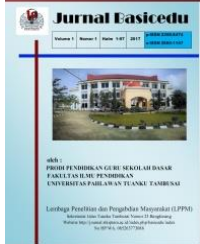

\title{
Pengembangan Media Komik Untuk Meningkatkan Minat Membaca Siswa Sekolah Dasar
}

\author{
Puji Handayani $^{1}$, Henny Dewi Koeswanti ${ }^{2}$ \\ Universitas Kristen Satya Wacana, Jawa Tengah, Indonesia \\ E-mail: 292016123@ student.uksw.edu ${ }^{1}$, henny.koeswanti@uksw.edu ${ }^{2}$
}

\begin{abstract}
Abstrak
Penelitian ini bertujuan untuk mengetahui tingkat minat membaca pada siswa kelas IV sekolah dasar menggunakan media komik. Jenis penelitian yang digunakan dalam penelitian ini adalah jenis penelitian pengembangan atau R\&D (research and development). Subjek penelitian ini yaitu siswa kelas IV SD Negeri Kutowinangun 05 Kecamatan Tingkir Kota Salatiga dengan jumlah 25 siswa. Instrumen penelitian ini berupa lembar validasi untuk ahli media dan lembar angket minat membaca siswa. Setelah dilakukan uji pakar berupa media diperoleh rata-rata 3,75 dengan persentase 79 yang termasuk katogori "tinggi" yang berarti media layak untuk digunakan. Teknik analisis data menggunakan teknik deskriptif dan teknik statistic uji Mann Whitney. Berdasarkan hasil uji yang dilakukan menggunakan Mann Whitney menunjukkan bahwa Sig. (2-tailed) sebesar 0,000 atau kurang dari 0,05, sehingga dapat dikatakan bahwa pretest dan posttest terdapat perbedaan yang signifikan. Sehingga dapat dikatakan bahwa media komik dapat meningkatkan minat membaca siswa.
\end{abstract}

Kata Kunci: Komik, Minat, Membaca

\begin{abstract}
This This study aims to determine the level of interest in reading in fourth grade elementary school students using comic media. This type of research used in this study is the type of research development or R\&D (research and development). The subjects of this study were grade IV students of SD Negeri Kutowinangun 05, Tingkir District, Salatiga City with a total of 25 students. The research instrument was in the form of a validation sheet for media experts and a student interest reading questionnaire sheet. After an expert test in the form of media obtained an average of 3.75 with a percentage of 79 which included the category of "high" which means the media is suitable for use. Data analysis techniques using descriptive techniques and Mann Whitney test statistical techniques. Based on the results of tests conducted using Mann Whitney shows that Sig. (2-tailed) of 0,000 or less than 0.05 , so it can be said that there are significant differences between pretest and posttest. So it can be said that comic media can increase students' interest in reading.
\end{abstract}

Keywords: Comics, Interests, Reading

@ Jurnal Basicedu 2020

$\triangle$ Corresponding author :

Address :

Email :

ISSN 2580-3735 (Media Cetak)

Phone

ISSN 2580-1147 (Media Online) 
397 Pengembangan media komik untuk meningkatkan minat membaca siswa sekolah dasar - Puji Handayani, Henny Dewi Koeswanti

\section{PENDAHULUAN}

Membaca merupakan jendela dunia. Ungkapan ini secara jelas menggambarkan manfaat membaca, yaitu membuka, memperluas wawasan dan pengetahuan individu. Membaca membuat individu dapat meningkatkan kecerdasan, mengakses informasi dan juga memperdalam pengetahuan dalam diri seseorang. Semakin sering membaca buku, semakin luas pengetahuan yang individu miliki. Sebaliknya, semakin jarang membaca buku, pengetahuan yang individu miliki semakin terbatas (Nasution dan Hidayah, 2019:105-106).

Di Indonesia, membaca menjadi salah satu aspek keterampilan berbahasa yang terdapat dalam kurikulum pembelajaran yang selalu ada dalam setiap tema pembelajaran. Membaca merupakan alternatif model pembelajaran (learning program) yang paling efektif, yaitu untuk mencapai tujuan pembelajaran dari seseorang tidak tahu menjadi tahu. Membaca juga alternatif terbaik untuk mendapatkan informasi sebagai model belajar (Ahmadi, 2010:65). Membaca menjadi hal yang menguntungkan bagi siswa dalam mencapai prestasinya yang didasarkan pada minat dari dalam agar semua yang dilakukan berhasil dengan baik dan lancar (Nursalina dan Budiningsih, 2014:2). Menurut Yetti (2009:19) minat merupakan motivator yang kuat untuk melakukan suatu aktivitas. Aktivitas membaca akan dilakukan oleh anak atau tidak, sangat ditentukan oleh minat anak terhadap aktivitas tersebut. Minat dapat diartikan sebagai suatu kecenderungan yang menyebabkan seseorang berusaha untuk mencari ataupun mencoba aktivitas-aktivitas dalam bidang tertentu. Minat juga diartikan sebagai sikap positif anak terhadap aspek-aspek lingkungan. Jadi dapat disimpulkan bahwa minat membaca adalah kekuatan yang mendorong anak untuk memperhatikan, merasa tertarik dan senang terhadap aktivitas membaca sehingga mereka mau melakukan aktivitas membaca dengan kemauan sendiri. Minat membaca tumbuh dari pribadi masing-masing seseorang, sehingga untuk meningkatkan minat membaca perlu kesadaran setiap individu. (Kasiyun, 2015:81-82).

Penulis melakukan studi pendahuluan dengan observasi dan mewawancarai guru kelas IV. Pada observasi dan wawancara terdapat beberapa faktor yang menjadi penghambat kurangnya minat membaca siswa diantaranya adalah kurangnya media belajar yang beragam untuk menyampaikan materi pelajaran. Sekolah membutuhkan media berupa komik yang sangat dibutuhkan siswa untuk mengembangkan imajinasinya, Masalah lain yang menjadi kendala dalam menarik minat membaca di sekolah tersebut yaitu ketersedian buku bacaan yang kurang bervariasi membuat siswa merasa kurang antusias untuk membaca. Maka dari itu diperlukan media belajar yang menarik minat siswa dalam membaca, yaitu melalui media komik.

Media pembelajaran yang dikemas dalam bentuk komik dapat digunakan sebagai salah satu variasi media pembelajaran. Media komik ini memiliki potensi untuk lebih disukai siswa, hal ini dikarenakan gambar dalam komik dapat menghidupkan deretan teks tertulis yang menyertainya. Dengan gambar, penjelasan panjang lebar dan rumit dari teks atau topik 
398 Pengembangan media komik untuk meningkatkan minat membaca siswa sekolah dasar - Puji Handayani, Henny Dewi Koeswanti

pembelajaran yang dibaca dapat menjadi lebih mudah dipahami dan diingat oleh siswa. Bahkan siswa dapat memahami dan membayangkan lebih dahulu apa yang sebenarnya menjadi inti dari topik pelajaran yang ia baca melalui gambar yang ada (Saputro dan Soeharto, 2015:64-65).

Komik adalah suatu bentuk kartun yang mengungkapkan karakter dan memerankan suatu cerita dalam urutan yang erat dihubungkan dengan gambar dan dirancang untuk memberikan hubungan kepada pembaca. Komik mempunyai peranan yang positif yaitu mengembangkan kebiasaan membaca. Dunia anak-anak penuh dengan imajinasi dan kreasi. Itulah sebabnya sebagian besar anak-anak menyukai gambar, sketsa dan komik. Komik adalah salah satu alat media yang menyenangkan untuk anak belajar (Hamida, Zulaekah, dan Mutalazimah, 2012:68).

Terdapat penelitian-penelitian yang pernah dilakukan sebelumnya membuktikan bahwa media komik dapat meningkatkan minat membaca siswa. Seperti penelitian yang telah dilakukan oleh Fahyuni dan Fauji (2017:25) Penggunaan komik Akidah-Akhlak di SD Muhammadiyah I Sidoarjo mampu meningkatkan minat membaca dan menimbulkan apresiasi positif dari peserta didik. Menurut penelitian yang juga dilakukan oleh Pratiwi dan Sudibyo (2018:294) mengatakan bahwa minat membaca siswa terhadap media komik sebesar 70,3\% termasuk dalam kategori cukup. Meskipun minat baca rata-rata siswa pada komik termasuk dalam kategori cukup namun data tersebut menunjukkan bahwa minat baca siswa terhadap media komik jauh lebih tinggi jika dibandingkan dengan minat baca siswa terhadap buku IPA. Penelitian yang sama juga dilakukakn oleh Lubis (2018:172) mengenai penelitian tentang bahan ajar komik untuk meningkatkan minat baca PPKn siswa kelas 5 (lima) MIN Ramba Padang kabupaten Tapanuli Selatan memperoleh hasil bahwa uji peningkatan skor minat baca PPKn diperoleh bahwa bahan ajar komik yang dikembangkan telah meningkatkan minat baca PPKn siswa sebesar 23,24 dengan kategori tinggi melalui pengukuran angket, dan sebesar 23,11 dengan kategori tinggi melalui pengukuran observasi pada uji coba pertama dan uji coba kedua.

Berdasarkan penelitian terdahulu mengenai media pembelajaran komik dalam meningkatkan minat membaca siswa, dan sesuai dengan kebutuhan siswa mengenai minat membaca, penulis tertarik untuk mengadakan penelitian pengembangan media komik untuk meningkatkan minat membaca siswa di sekolah dasar. Penelitian ini hendak membuktikan apakah komik yang dibuat peneliti mampu meningkatkan minat membaca siswa.

\section{METODE}

Penelitian yang digunakan merupakan jenis penelitian pengembangan atau $R \& D$ (research and development). Penelitian pengembangan merupakan penelitian yang bertujuan untuk menghasilkan atau mengembangkan suatu produk baru atau menyempurnakan produk yang sudah ada, yang dapat dipertanggungjawabkan (Sukmadinata, 2016:163). Penelitian ini menghasilkan produk media pembelajaran komik yang bertujuan untuk meningkatkan minat membaca siswa sekolah dasar kelas IV. Model pengembangan yang digunakan yaitu model pengembangan yang mengacu pada 
399 Pengembangan media komik untuk meningkatkan minat membaca siswa sekolah dasar - Puji Handayani, Henny Dewi Koeswanti

langkah-langkah dari Borg and Gall, yang terdiri dari studi pendahuluan, pengembangan produk, dan uji produk.

Penelitian ini dilaksanakan di SD Negeri Kutowinangun 05 Kecamatan Tingkir, Kota Salatiga dengan subjek penelitian yaitu siswa kelas IV dengan jumlah 25 siswa. Sedangkan objek penelitian ini adalah pengembangan media komik. Teknik pengumpulan data pada penelitian ini menggunakan teknik pengumpulan data non tes. Teknik non tes yang digunakan berupa angket yang diisi oleh siswa. Teknik analisis data yang digunakan dalam penelitian ini menggunakan teknik deskriptif dan teknik statistik uji Mann Whitney.

\section{HASIL DAN PEMBAHASAN}

Penelitian ini dilaksanakan di kelas IV SD Negeri Kutowinangun 05 yang berada di Kecamatan Tingkir Kota Salatiga semester II tahun pelajaran 2019/2020 dengan jumlah siswa kelas IV yaitu 25 siswa. Penelitian ini dilaksanakan pada hari Jumat, 13 Maret 2020 untuk pretest, dan hari Sabtu, 14 Maret 2020 untuk posttest menggunakan media komik. Pada tahap penelitian ini mengkaji konsep mengenai meningkatkan minat membaca berupa media komik yang akan dikembangkan dengan mengangkat Tema 6 "Cita-Citaku", Subtema 1 "Aku dan Cita-Citaku", Pembelajaran 1. Penyusunan produk awal komik dilakukan dengan menentukan tema, subtema, dan pembelajaran, selanjutnya menyusun sketsa dan desain komik. Uji validitas media komik yang dilaksanakan mendapatkan rata-rata 3,75 dengan persentase 79 yang termasuk katogori "tinggi" tetapi masih membutuhkan revisi untuk desain tulisan dan layout, setelah di lakukan revisi kemudian dilaksanakan pengujian di sekolah. setelah itu dilakukan uji statistic deskriptif untuk mengetahui rerata seperti tabel berikut ini:

Tabel 1. Statistik Deskriptif

\section{Descriptive Statistics}

\begin{tabular}{|c|c|c|c|c|c|c|c|c|c|c|}
\hline \multirow[t]{2}{*}{ Parameter } & \multirow{2}{*}{$\begin{array}{l}\mathrm{N} \\
\text { Statis } \\
\text { tic }\end{array}$} & \multirow{2}{*}{ 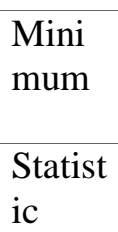 } & \multirow{2}{*}{ 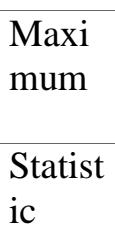 } & \multicolumn{2}{|l|}{ Mean } & \multirow{2}{*}{$\begin{array}{l}\text { Std. } \\
\text { Deviatio } \\
\mathrm{n} \\
\text { Statistic }\end{array}$} & \multicolumn{2}{|c|}{ Skewness } & \multicolumn{2}{|c|}{ Kurtosis } \\
\hline & & & & $\begin{array}{l}\text { Statis } \\
\text { tic }\end{array}$ & $\begin{array}{l}\text { Std. } \\
\text { Error }\end{array}$ & & $\begin{array}{l}\text { Statis } \\
\text { tic }\end{array}$ & $\begin{array}{l}\text { Std. } \\
\text { Error }\end{array}$ & $\begin{array}{l}\text { Statis } \\
\text { tic }\end{array}$ & $\begin{array}{l}\text { Std. } \\
\text { Error }\end{array}$ \\
\hline Pretest & 25 & 63 & 79 & 70.48 & .740 & 3.698 & .423 & .464 & .631 & .902 \\
\hline Posttest & 25 & 74 & 89 & 80.76 & .827 & 4.136 & .516 & .464 & -.687 & .902 \\
\hline $\begin{array}{l}\text { Valid N } \\
\text { (listwise) }\end{array}$ & 25 & & & & & & & & & \\
\hline
\end{tabular}


400 Pengembangan media komik untuk meningkatkan minat membaca siswa sekolah dasar - Puji Handayani, Henny Dewi Koeswanti

Dari tabel 1 menunjukkan jumlah responden adalah 25 siswa. Dari 25 siswa ini pada pretest menunjukkan hasil minimum berjumlah 63 dan pada posttest berjumlah 74 . Nilai maksimum pada posttest berjumlah 79 dan pada posttest berjumlah 89. Rata-rata nilai pretest berjumlah 70.48 dengan standar Deviation sebesar 3.688 dan nilai rata-rata dari posttest berjumlah 80.76 dengan standar Deviation sebesar 4.136. nampak bahwa skor minimum, maksimum, dan skor rata-rata minat membaca terbukti bahwa postest lebih tinggi dibandingkan dengan pretest.

Tabel 2. Uji Mann Whitney

\begin{tabular}{l|r}
\hline Test Statistics & \multicolumn{1}{|c}{ Hasil } \\
\hline Mann-Whitney U & 19.000 \\
\hline Wilcoxon W & 344.000 \\
\hline Z & -5.710 \\
\hline Asymp. Sig. (2-tailed) & .000 \\
\hline \multicolumn{2}{|l}{ a. Grouping Variable: Perlakuan } \\
\hline
\end{tabular}

Tabel diatas menunjukkan nilai $\mathrm{U}$ sebesar 19.000 dan nilai $\mathrm{W}$ sebesar 344.000. apabila dikonversikan ke $\mathrm{Z}$ maka nilai hasil -5.710. nilai Sig. (2-tailed) sebesar 0,000 atau kurang dari 0,05, sehingga dapat dikatakan bahwa pretest dan posttest terdapat perbedaan yang signifikan. Sehingga dapat dikatakan bahwa media komik dapat meningkatkan minat membaca siswa.

Berdasarkan hasil penelitian dan pengolahan data yang telah dilakukan untuk mengetahui minat membaca siswa SD, diperoleh hasil bahwa media pembelajaran komik dapat meningkatkan minat membaca siswa.

Media komik memberikan dampak yang lebih tinggi terhadap minat yang lebih tinggi terhadap minat mebaca siswa. Seperti penelitian yang dilakukan oleh Fahyuni dan Fauji (2017:25) Penggunaan komik Akidah-Akhlak di SD Muhammadiyah I Sidoarjo mampu meningkatkan minat membaca dan menimbulkan apresiasi positif dari peserta didik. Hasil penelitian ini sejalan dengan penelitian yang dilakukan oleh Pratiwi dan Sudibyo (2018:294) mengatakan bahwa minat membaca siswa terhadap media komik sebesar 70,3\% termasuk dalam kategori cukup. Meskipun minat baca rata-rata siswa pada komik termasuk dalam kategori cukup namun data tersebut menunjukkan bahwa minat baca siswa terhadap media komik jauh lebih tinggi jika dibandingkan dengan minat baca siswa terhadap buku IPA. Penelitian ini juga dilakukann oeh Lubis (2018:172) mengenai penelitian tentang bahan ajar komik untuk meningkatkan minat baca PPKn siswa kelas 5 (lima) MIN Ramba Padang kabupaten Tapanuli Selatan memperoleh hasil bahwa uji peningkatan skor minat baca PPKn diperoleh bahwa bahan ajar komik yang dikembangkan telah meningkatkan minat baca PPKn siswa sebesar 23,24 dengan kategori tinggi melalui pengukuran angket, dan sebesar 23,11 dengan kategori tinggi melalui pengukuran observasi pada uji coba pertama dan uji coba kedua. Hasil penelitian ini dapat memperkuat keampuhan mengenai minat membaca dengan menggunakan media komik.

\section{SIMPULAN}

Berdasarkan hasil penelitian yang telah dilaksanakan tentang meningkatkan minat membaca siswa menggunaan media komik diperoleh hasil bahwa media komik dapat meningkatkan minat membaca siswa hal ini dibuktikan dengan media diperoleh rata-rata 3,75 dengan persentase 79 yang termasuk katogori "tinggi” yang berarti media layak untuk digunakan. Teknik analisis data menggunakan teknik deskriptif dan teknik statistic uji Mann Whitney. Berdasarkan hasil uji yang dilakukan menggunakan Mann Whitney menunjukkan bahwa Sig. (2-tailed) sebesar 0,000 atau kurang dari 0,05, sehingga dapat dikatakan bahwa pretest dan posttest terdapat perbedaan yang signifikan. 
401 Pengembangan media komik untuk meningkatkan minat membaca siswa sekolah dasar - Puji Handayani, Henny Dewi Koeswanti

Sehingga dapat dikatakan bahwa media komik dapat meningkatkan minat membaca siswa.

Semoga penelitian ini dapat menjadi acuan untuk penelitian selanjutnya dan hasil penelitian ini dapat direkomendasi untuk diimplementasikan.

\section{DAFTAR PUSTAKA}

Ade Irma Nursalina, Tri Esti Budiningsih. 2013. "Educational Psychology Journal." Educational Psychology Journal 2 (1): 2.

Ahmadi, Farid. 2010. "Meningkatkan Minat Membaca Siswa Sekolah Dasar Dengan Metode Glenn Doman Berbasis Multimedia." Jurnal Penelitian PendidikanA \& A (Semarang) $27 \quad$ (1): 65 https://doi.org/10.15294/jpp.v27i1.194.

Eni Fariyatul Fahyuni, Imam Fauji. 2017. "Pengembangan Komik Akidah Akhlak Untuk Mengingkatkan Minat Baca Dan Prestasi Belajar Siswa Sekolah Dasar." Halaqa:Islamic Edication Journal 1: 25.

Hengkang Bara Saputro, Soeharto. 1946. "Early Clinical and Roentgenologic Diagnosis of Anencephaly." American Journal of Obstetrics and Gynecology 51 (4): 64-65. https://doi.org/10.1016/S00029378(15)30176-9.

Kartika Putri Pratiwi, Elok Sudibyo. 2018. "Keefektifan Penggunaan Media Pembelajaran Komik Pada Materi Gerak Untuk Meningkatkan Minat Baca Siswa Smp Kelas Viii.” Pendidikan Sains 6 (02): 294

Kasiyun, Suharmono. 2015. "Jurnal Pena Indonesia (JPI) Jurnal Bahasa Indonesia, Sastra, Dan Pengajarannya." Jurnal Pena Indonesia 1 (1): 81-82.

Khairuna Hamida, Siti Zulaekah, Mutalazimah. 2012. "Penyuluhan Gizi Dengan Media Komik Untuk Meningkatkan Pengetahuan Tentang Keamanan Makanan Jajanan." Penyuluhan Gizi Dengan Media Komik Untuk Meningkatkan Pengetahuan Tentang Keamanan Makanan Jajanan 8 (1): 68. https://doi.org/10.15294/kemas.v8i1.2261.

Lubis, M. A. (2018). Pengembangan Bahan Ajar Komik Untuk Meningkatkan Minat Baca PPKn Siswa MIN Ramba Padang Kabupaten Tapanuli Selatan. Jurnal Tarbiyah, 25(2).

Nasution, Anwar Efendi. 2019. "E-KOMPEN (ELEKTRONIK-KOMIK PENDEK) Sebagai Solusi Cerdas Dalam Meningkatkan Minat Baca Masyarakat Indonesia Di Era Digital." IQRA : Jurnal Ilmu Perpustakaan Dan Informasi (e-Journal) 13 (1): 105-6. https://doi.org/10.30829/iqra.v13i1.4365.

Sukmadinata. 2016. Metode Penelitian Pendidikan. Bandung: Remaja Rosdakarya.

Yetti, Rivda. 2009. "Pengaruh Keterlibatan Orang Tua Terhadap Minat Membaca Anak Ditinjau Dari Pendekatan Stres Lingkungan." PEDAGOGI | Jurnal Ilmiah Ilmu Pendidikan IX $\quad$ (1): 19. http://ejournal.unp.ac.id/index.php/pedagogi 